\title{
PENDIDIKAN KARAKTER DAN PENDIDIKAN AKHLAK
}

\author{
(Studi Perbandingan) \\ Oleh : Ahmad Rifa'i*
}

\section{Abstrak}

Ada nilai-nilai karakter yang menjadi prioritas utama. Diantaranya adalah jujur, toleransi, demokrasi, suka menolong, cinta kedamaian. Karena kondisi Negara Indonesia saat ini dengan rusaknya moral dan semakin parah. Maka nilai-nilai itu yang dianggap sangat dibutuhkan. Dan kesemuanya itu adalah nilai-nilai kemanusiaan (Humanis) yang lebih mengutamakan perlakuan baik terhadap sesama manusia. Karena tujuan dari pendidikan karakter adalah menjadi manusia yang baik. Perlu kita cermati bersama, bahwa nilai-nilai tersebut terlihat sangat baik dan sesuai dengan kemanusiaan. Tapi masih belum sepenuhnya bisa diterima oleh Islam dan masih harus dipertanyakan lebih mendalam. Seperti "Jujur", dalam Islam tak selamanya kita harus jujur kepada siapa saja. Ada porsi dan posisi serta kondisi yang harus dipertimbangkan. Sebagai contoh, ketika perang dan tertangkap menjadi tawanan. Maka ia sebagai seorang muslim tidak boleh jujur mengatakan dimana letak kelemahan kaum muslim walaupun harus mempertaruhkan nyawanya demi agamanya. Dan pada saat itu ia termasuk muslim yang berakhlak mulia. pada umumnya karakter adalah sesuatu yang baik. Karakter jujur, toleran, kerja keras, dan sebagainya, memang sesuatu yang didambakan manusia. Namun tanpa disertai akhlak, karakter itu akan dapat melampaui batas-batas ajaran agama. Sebagai contoh, karakter toleran. Toleransi saja tidak cukup. Toleran terhadap apa? Seorang muslim tidak boleh bersikap toleran terhadap kemusyrikan atau kemunkaran. Sebab, setiap muslim berkewajiban menjalankan amar ma'ruf nahi munkar

Kata Kunci:Pendidikan, karakter, akhlak

\section{Pendahuluan}

Pendidikan karakter semakin hangat dibicarakan sebagai solusi atas merosotnya ${ }^{1}$ kualitas pendidikan di Indonesia. Karena sistim

\footnotetext{
* Penulis adalah dosen Sekolah Tinggi Ilmu AlQuran (STIQ) Amuntai Kalimantan Selatan. Menyelesaikan S2 di SPs UIN Maulana Malik Iberahim Malang

${ }^{1}$ Kondisi moral generasi muda yang rusak/hancur. Hal ini ditandai dengan maraknya seks bebas, peredaran narkoba, tawuran pelajar, peredaran foto dan video porno dan sebagainya. Data hasil survey mengenai seks bebas di kalangan remaja Indonesia menunjukan 63\% remaja Indonesia melakukan seks bebas. Menurut direktur Remaja dan Pelindungan Hak-Hak Reproduksi BKKBN, M. Masri Muadz, data itu merupakan hasil
} 
pendidikan yang ada selama ini dianggap gagal. Lulusan sekolah atau sarjana yang dihasilkan piawai dalam menjawab soal ujian, berotak cerdas, namun mental dan moralnya lemah. ${ }^{2}$ Banyak ilmu yang dimiliki, namun dipakai untuk mengambil keuntungan untuk diri sendiri tanpa memperdulikan orang lain yang ada disekitarnya. Sementara orang-orang disekelilingnya banyak yang tersakiti akibat perbuatannya. Dengan demikian dalam laporan tahunan Character Education Partnership disebutkan bahwa pendidikan karakter bagi sekolah bukan lagi sebagai sebuah opsi, tetapi suatu keharusan yang tak terhindarkan ${ }^{3}$.

Pemerintah Indonesia, melalui Kementerian Pendidikan Nasional sudah mencanangkan penerapan Pendidikan karakter untuk semua tingkat pendidikan, mulai dari SD sampai Perguruan Tinggi. Menurut Mendiknas, Prof. Muhammad Nuh, pembentukan karakter perlu dilakukan sejak usia dini. Jika karakter sudah terbentuk sejak usia dini,

survey oleh sebuah lembaga survey yang mengambil sampel di 33 provinsi di Indonesia pada tahun 2008. Sedangkan remaja korban narkoba di Indonesia ada 1,1 juta orang atau 3,9\% dari total jumlah korban. Pengangguran terdidik (lulusan SMA, SMK dan perguruan tinggi) yang makin meningkat.Data Badan Pusat Statistik atau BPS menyebutkan, lulusan SMK tertinggi yakni 17,26\%, disusul tamatan SMA (Sekolah Menengah Atas) 14,31\%, lulusan universitas 12,59\%, serta diploma I/II/III 11,21\%. Tamatan SD ke bawah justru paling sedikit menganggur yakni 4,56\% dan SMP 9,39\%. Ditambah lagi dengan para pejabat yang melakukan praktek korupsi tidak dapat disembunyikan lagi. Korupsi semakin bertambah merajalela. Berdasarkan Indeks Persepsi Korupsi (IPK) Indonesia tahun 2009 ini naik menjadi 2,8\% dari 2,6\% pada tahun 2008. Dengan skor ini, peringkat Indonesia terdongkrak cukup signifikan, yakni berada di urutan 111 dari 180 negara (naik 15 posisi dari tahun lalu) yang di survai IPK-nya oleh Transparancey International (TI). Bencana yang sering berulang-ulang diduga sebagai azab atau lemahnya bangsa ini dalam memecahkan masalah lingkungan, seperti banjir, longsor, dan kebakaran. Wilayah Indonesia dilanda 6.632 kali bencana selama kurun waktu 13 tahun (1997-2009) yang menunjukkan negara ini sebagai daerah rawan bencana di dunia. Bencana paling banyak terjadi pada tahun 2008 yang mancapai 1.302 kali. (Ridwan Yunus: programme Asociate Crisis Prevention and Rocovery unti lembaga PBB, UNDP yang juga korrdinator Pusat Data Badan Nasional Penanggulangan Bencana). Kemiskinan yang semakin hari semakin bertambah. Daya kompetitif yang rendah, sehingga banyak produk dalam negeri dan sumber daya manusia yang tergantikan oleh produk dan sumber daya manusia dari negeri tetangga dan luar negeri. Lihat Dharma Kesuma, DKK, Pendidikan Karakter Kajian Teori dan Praktik di Sekolah, (Bandung: PT. Remaja Rosdakarya, 2011), hal. 3-4

${ }^{2}$ Adian Husaini, Pendidikan Islam Membentuk Manusia Berkarakter dan Beradab, (Depok: Kemunitas NuuN, 2011), h. 37

${ }^{3}$ Abdul Majid dan Dian Andayani, Pendidikan Karakter Perspektif Islam, (Bandung: PT. Remaja Rosdakarya, 2011), hal. 6

Jurnal Ilmiah Al QALAM, Vol. 9, No. 17, Januari-Juni 2016 
maka tidak akan mudah untuk mengubah karakter seseorang. Ia juga berharap, pendidikan karakter dapat membangun kepribadian bangsa. Mendiknas mengungkapkan hal ini saat berbicara pada pertemuan Pimpinan Pascasarjana Lembaga Pendidikan Tenaga Kependidikan (LPTK) se-Indonesia di Auditorium Universitas Negeri Medan (Unimed), Sabtu (15/4/2010). ${ }^{4}$ Dengan demikian maka sudah jelaslah bahwa pendidikan karakter akan menjadi sebuah sistim pendidikan yang akan dijalankan di Indonesia untuk saat ini.

Namun yang menjadi permasalahnnya adalah apakah pendidikan karakter sudah tepat untuk dijadikan solusi? Apakah cukup hanya dengan pendidikan karater? Penulis akan mengulas apakah pendidikan karakter yang sedang ramai dibicarakan oleh para pakar pendidikan, sudah benarbenar menjadi solusi dalam mengatasi permasalah pendidikan di Indonesia atau tidak, yang notabenenya adalah mayoritas muslim. Penulis mengkomparasikan dengan pendidikan Akhlak. Karena dalam Islam terdapat pedidikan Akhlak yang seharusnya menjadi pedoman setiap muslim untuk menjadi muslim yang sejati dan berkepribadian Islami.

\section{Pendidikan Karakter}

Kata pendidikan (tarbiyah) menurut Suwaid memiliki tiga kata dasar yaitu : dari kata rabaa-yarbuu (bertambah dan berkembang), rabaayarbii (tumbuh dan mekar), rabba-yarubbu (memperbaiki dan mengurus suatu perkara). Kata tarbiyah menurut Miqdad Yaljan adalah bertambah, memberi makan, memerlihara, menjaga dan tumbuh, juga digunakan secara majazi dengan arti mendidik tingkah laku dan meninggikan pangkat. Makna lainnya yang senada adalah berkembang, memberi makan, meninggikan dan mengangkat posisi. Pengambilan kata tarbiyah ini juga dari kata rabb dan bukan dari raba sehingga bisa dikatakan pula mendidik anak artinya memperhatikannya dengan baik, mengajari sampai bisa dan akhirnya menyapihnya. ${ }^{5}$

${ }^{4}$ Adian Husaini, Pendidikan Islam....., hal. 37

${ }^{5}$ Ar-Raghib Al-Asfahani mengatakan, Ar-Rabb itu asalnya adalah at-tarbiyah yakni menumbuhkan sesuatu dari satu keadaan ke keadaan yang lain hingga mencapai batas kesempurnaan. Menurut Naquib Al-Attas, jika penggunaan kata rabb sama dalam bentuk madi (past tense), (seperti pada ayat al-Isra 34 :kama rabbayani shaghira) dan mudari'nya

Jurnal Ilmiah Al QALAM, Vol. 9, No. 17, Januari-Juni 2016 
Pendidikan menurut John Dewey adalah proses pembentukan kecakapan fundamental secara intelektual dan emosional ke arah alam dan sesama manusia ${ }^{6}$. Tujuan pendidikan dalam hal ini agar generasi muda sebagai penerus generasi tua dapat menghayati, memahami, mengamalkan nilai-nilai atau norma-norma tersebut dengan cara mewariskan segala pengalaman, pengetahuan, kemampuan dan keterampilan yang melatarbelakangi nilai-nilai dan norma-norma hidup dan kehidupan.

Karakter berasal dari bahasa Latin "kharakter", "kharassein", "kharax", dalam bahasa Inggris: character dan Indonesia "karakter", Yunani character, dari charassein yang berarti membuat tajam, membuat dalam. Dalam kamus Poerwadarminta, karakter diartikan sebagai tabiat, watak, sifat-sifat kejiwaan, akhlak atau budi pekerti yang membedakan seseorang dengan yang lain. ${ }^{7}$ Sebagaimana juga didefinisikan oleh

(present tense) (seperti pada ayat As-Syuara' 18 : alam rubabbika fiina waliida), maka ini bermakna pendidikan, tanggung jawab, memberi makan, perkembangan dan pertumbuhan. Oleh sebab itu untuk mengungkapkan pendidikan ada beberapa kata yang sesuai diantaranya kata irshad, tahdhib, siyasah, dan ta'dib. Lihat Ahmad Tufiq, Pendidikan Agama Islam: Pendidikan Karakter Berbasis Agama Islam,( Surakarta: Yuma Pustaka, 2011), hal. 218

${ }^{6}$ Masnur Muslich, Pendidikan Karakter......, hal. 67

${ }^{7}$ Nama dari jumlah seluruh ciri pribadi yang meliputi hal-hal seperti perilaku, kebiasaan, kesukaan, ketidaksukaan, kemampuan, kecenderungan, potensi, nilai-nilai, dan pola-pola pemikiran. (Hornby dan Parnwell, 1972: 49) karakter adalah kualitas mental atau moral, kekuatan moral, nama atau reputasi. Hermawan Kertajaya (2010: 3) mendefinisikan karakter adalah "ciri khas" yang dimiliki oleh suatu benda atau individu. Ciri khas tersebut adalah "asli" dan mengakar pada kepribadian benda atau individu tersebut dan merupakan 'mesin' pendorong bagaimana seorang bertindak, bersikap, berujar, dan merespons sesuatu. Lihat Abdul Majid dan Dian Andayani, Pendidikan Karakter Perspektif Islam, (Bandung: PT Remaja Rosdakarya, 2011), h. 11. Ditambah lagi Karakter adalah sifat baik yang menjadi perilaku sehari-hari. Tapi bila belum jadi perilaku, sifat baik itu masih jadi nilai. Kemudian jika sudah jadi perilaku baik, ternyata tidak cukup sekedar berperilaku baik. Orang pendiam belum tentu karena 'rendah hati'. Jangan-jangan "rendah diri'. Peragu bisa berdalih karena penuh pertimbangan. Orang santun juga belum tentu memang baik hatinya. Pendiam dan santun hanyalah gaya. Tidak berarti orang yang blak-blakan dan tegas pastilah jahat. Lihat Erie Sudewo, Best Practice Charater Building Menuju Indonesia Lebih Baik, (Jakarta: PT Gramedia, 2011), h. 45. Karakter juga diartikan merupakan sesuatu yang mengualifikasikan seorang pribadi (Foerster); keadaan jiwa yang menyebabkan seseorang bertindak tanpa dipikirkan terlebih dahulu (Ibnu Miskawaih); sifat alami seseorang dalam merespons situasi secara bermoral (Thomas Lickona); cara berfikir dan berperilaku yang menjadi ciri khas tiap individu untuk hidup dan bekerjasama, baik dalam lingkup keluarga, masyarakat, bangsa dan negara (Suyanto); untuk lebih lengkapnya baca di Agus Wibowo, Pendidikan Karakter

Jurnal Ilmiah Al QALAM, Vol. 9, No. 17, Januari-Juni 2016 
Thomas Lickona, mengandung tiga unsur pokok, yaitu mengetahui kebaikan (knowing the good), mencintai kebaikan (loving the good), dan melakukan kebaikan (doing the good). ${ }^{8}$ Dalam pendidikan karakter, kebaikan itu sering kali dirangkum dalam sederet sifat-sifat baik. Seperti halnya dalam sebuah penelitian mengenai pendidikan karakter menyebutkan bahwa pendidikan karakter/akhlak merupakan langkah penting dan strategis dalam membangun kembali jati diri individu maupun bangsa. Tetapi penting untuk segera dikemukakan bahwa pendidikan karakter haruslah melibatkan semua pihak, rumah tangga dan keluarga, sekolah, dan lingkungan sekolah lebih luas (masyarakat). ${ }^{9}$

Dengan demikian, maka pendidikan karakter adalah sebuah upaya untuk membimbing perilaku manusia menuju standar-standar baku yang berlandaskan kepada nilai-nilai, norma-norma hidup dan kehidupan. Maka upaya ini menjadi jalan untuk menghargai persepsi dan nilai-nilai pribadi yang ditampilkan. Dan fokus pendidikan karakter adalah pada tujuan-tujuan etika, tetapi praktiknya meliputi penguatan kecakapankecakapan yang penting yang mencakup perkembangan sosial siswa. ${ }^{10}$ Sehingga tercapailah manusia yang baik di tengah-tengah masyarakat.

\section{Pendidikan Akhlak}

Akhlak adalah kata jama' dari kata khulq. Akar katanya serumpun dengan khalaqa (menciptakan). Artinya adalah sifat jiwa yang melekat (malakah) dalam diri seseorang sesuai dengan asal mula diciptakannya (ahsanu taqwim). Alasannya jelas, jiwa manusia itu diciptakan Allah dengan fitrah-Nya (fitratallah alliti fatarannas alaiha). Maka itu, berakhlak adalah berpikir, berkehendak, dan berperilaku sesuai dengan fitrahnya (nurani). ${ }^{11}$ Menurut logat juga akhlak ${ }^{12}$ diartikan budi pekerti,

Strategi Membangun Karakter Bangsa Berperadaban, (Yogyakarta: Pustaka Pelajar, 2012), hal. 35.

${ }^{8}$ Thomas Lickona,Educating For Character: How Our School Can Teach Respect and Responsibility, (New York:Bantam Books, 1992), hal. 23

9 Agus Setiawan, Prinsip Pendidikan Karakter dalam Islam (Studi Komparasi Pemikiran al-Ghazali dan Burhanuddin al-Zarnuji), Dinamika Ilmu, 14 (1), 2014, hal. 8

${ }^{10}$ Abdul Majid dan Dian Andayani, Pendidikan Karakter...... hal. 11

${ }^{11}$ Hamid Fahmy Zarkasyi, Akhlak, dalam Republika-Islamia, 15 September 2011

Jurnal Ilmiah Al QALAM, Vol. 9, No. 17, Januari-Juni 2016 
perangai, tingkah laku atau tabiat. Rumusan pengertian akhlak timbul sebagai media yang memungkinkan adanya hubungan baik antara Khaliq dan makhluk serta antara makhluk dan makhluk. Sesuai dengan firman Allah dalam Al-Qur'an ${ }^{13}$ dan hadits Nabi Saw. ${ }^{14}$

Dan atas dasar itu juga, Akhlak adalah suatu ilmu yang menjelaskan arti baik dan buruk, menerangkan apa yang seharusnya dilakukan oleh makhluk kepada yang lainnya, serta apa yang seharusnya dilakukan makhluk kepada sang Kholiq. ${ }^{15}$ Berbuat sesuai dengan fitrah dari penciptaan setiap makhluk tersebut. Kita hidup di dunia ini atas izin sang Kholiq. Semua yang ada adalah atas kehendakNya. Maka setiap bersikap dan berprilaku juga harus memperhatikan ketentuan-ketentuan yang telah ditetapkan olehNya. Mana yang seharusnya dilakukan dan mana yang seharusnya ditinggalkan. Selain daripada itu, bersikap dan berprilaku kepada sesama makhluk haruslah dengan baik. Apalagi bersikap kepada Kholiq. Jangan sampai menafikan sang Kholiq demi mendapat pujian dari sesama makhluk. Justru seharusnya tetap mengutamakan sang Kholiq daripada makhluk. Karena ada hal-hal yang dibenci oleh Kholiq namun disukai oleh makluk, ataupun sebaliknya.

Pendidikan akhlak sebagaimana dirumuskan oleh Ibn Miskawaih adalah keadaan jiwa yang menyebabkan seseorang bertindak tanpa dipikirkan terlebih dahulu. Ia menyebutkan adanya dua sifat yang menonjol dalam jiwa manusia, yaitu sifat buruk dari jiwa yang pengecut, sombong, dan penipu, dan sifat jiwa yang cerdas yaitu adil, pemberani,

${ }^{12}$ Akhlak adalah suatu keadaan yang melekat pada jiwa manusia, yang daripadanya lahir perbuatan-perbuatan dengan mudah, tanpa melalui proses pemikiran, pertimbangan atau penelitian. Jika keadaan (hal) itu melahirkan perbuatan yang baik dan terpuji menurut pandangan akal dan syarak (hukum Islam), keadaan tersebut disebut akhlak yang baik, sedangkan jika perbuatan-perbuatan yang timbul itu tidak baik, dinamakan akhlak yang buruk. Kata akhlak merupakan bentuk jamak dari kata al-khuluq atau al-khulq, yang secara etimologis berarti (1) "tabiat, budi pekerti", (2) "kebiasaan atau adat", (3) "keperwiraan, kesatriaan, kejantanan", (4) "agama", dan (5) "kemarahan (al-ghadhab)". Lihat Zeni Luthfiah, dkk, Pendidikan Agama Islam : Pendidikan Karakter Berbasis Agama Islam, (Surakarta: Yuma Pustaka, 2011), hal. 28

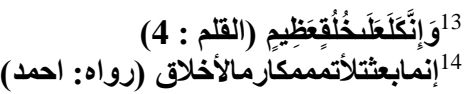

${ }^{15}$ Abdul Majid dan Dian Andayani, Pendidikan Karakter...... hal. 10

Jurnal Ilmiah Al QALAM, Vol. 9, No. 17, Januari-Juni 2016 
pemurah, sabar, benar, tawakal, dan kerja keras. ${ }^{16}$ Sehingga yang dididik adalah sifat asli yang terdapat dalam fitrah manusia tersebut. Dalam pendidikan akhlak ini, kriteria benar dan salah untuk menilai perbuatan yang muncul merujuk pada Al-Qur'an dan Sunnah sebagai sumber tertinggi ajaran Islam. ${ }^{17}$

Al-Ghazali yang bernama lengkap Abu Hamid Muhammad bin Muhammad al-Ghazali memberikan kriteria terhadap akhlak yang mirip dengan Ibn Miskawaih, yaitu bahwa akhlak harus menetap dalam jiwa dan perbuatan itu muncul dengan mudah tanpa memerlukan pemikiran yang mendalam atau penelitian terlebih dahulu. Akhlak bukan merupakan "perbuatan", bukan "kekuatan", bukan "ma'rifah" (mengetahui dengan mendalam). Yang lebih sepadan dengan akhlak itu adalah "hal" keadaan atau kondisi jiwa yang bersifat bathiniah". ${ }^{18}$

Kemudian akhlak juga dikatakan adalah keadaan batin seseorang yang menjadi sumber lahirnya perbuatan dimana perbuatan itu lahir dengan mudah tanpa memikirkan untung dan rugi. Orang yang berakhlak baik akan melakukan kebaikan secara spontan tanpa pamrih. Sehingga gemar melakukan kebaikan kepada siapa saja tanpa melanggar aturan dan tatanan yang telah ditentukan oleh sang Kholiq.

Dengan demikian maka pendidikan akhlak bisa dikatakan juga sebagai pendidikan moral dalam diskursus pendidikan Islam. Telaah lebih dalam terhadap konsep akhlak yang telah dirumuskan oleh para tokoh pendidikan Islam masa lalu seperti Ibnu Miskawaih, Al-Qabisi, AlGhazali menunjukkan bahwa tujuan puncak pendidikan akhlak adalah terbentuknya karakter anak didik dengan berakhlak mulia. Yang tiada lain adalah penjelmaan sifat-sifat mulai Allah dalam kehidupan manusia sesuai fitrahnya. ${ }^{19}$

\section{Pebandingan Antara Pendidikan Karakter dan Pendidikan Akhlak}

\footnotetext{
${ }^{16}$ Ibn Miskawaih, Tahdzib al-Akhlak, (Beirut: Dar el Kutb al-Taymiyyah, 1405H/1985M), hal. 21

${ }^{17}$ Abdul Majid dan Dian Andayani, Pendidikan Karakter...... hal. 10

${ }^{18}$ Al-Ghazali, Ihya Ulumuddin, (Qairo, Mesir: Daar al-Taqwa, 2000), jilid 2, hal.599

${ }^{19}$ Abdul Majid dan Dian Andayani, Pendidikan Karakter...... hal. 10.
}

Jurnal Ilmiah Al QALAM, Vol. 9, No. 17, Januari-Juni 2016 
Pendidikan karakter akan menciptakan manusia memiliki ciri khas pribadi sesuai dengan nilai-nilai yang ditanamkan dalam sistem pendidikan disekolah atau lingkungannya. Maka nilai dan prinsip-prinsip yang ditanamkan dan diajarkan sangat berpengaruh terhadap hasil yang akan dicapai. Jika selama menjalani proses pendidikannya yang dididik adalah nilai kejujuran maka akan melekat pada diri anak didik kejujuran tersebut kapan dan dimana pun berada. Jika sejak dini dididik dengan keberanian maka dia pun akan muncul sebagai seorang pemberani di masa yang akan datang. Bahkan jika dididik dengan hal-hal negatif sejak kecilnya maka akan mengakar juga pada diri anak nilai negatif tersebut dan sangat sulit untuk mengubahnya. Hasil dari proses yang dilakukan terhadap anak didik itulah yang akan menjadi karakter pribadinya dimana pun ia berada.

Maka untuk itu perlu kita lihat karakter bagaimana yang akan ditanamkan kepada seluruh anak dan generasi muda di Indonesia ini. Nilai-nilai karakter yang perlu ditanamkan menurut Indonesia Heritage Foundation (IHF) ${ }^{20}$

\begin{tabular}{|c|l|}
\hline No & \multicolumn{1}{|c|}{ Karakter } \\
\hline 1 & $\begin{array}{l}\text { Cinta Tuhan dan segenap ciptaan-Nya (love Allah, trust, } \\
\text { reverence, loyalty) }\end{array}$ \\
\hline 2 & $\begin{array}{l}\text { Kemandirian dan tanggung jawab (responsibility, excellence, } \\
\text { self reliance, discipline, orderliness) }\end{array}$ \\
\hline 3 & $\begin{array}{l}\text { Kejujuran/amanah, bijaksana (trustworthiness, reliability, } \\
\text { honesty) }\end{array}$ \\
\hline 4 & Hormat dan santun (respect, courtesy, obedience) \\
\hline 5 & $\begin{array}{l}\text { Dermawan, suka menolong dan gotong royong (love, } \\
\text { compassion, caring, empathy, generousity, moderation, } \\
\text { cooperation) }\end{array}$ \\
\hline 6 & $\begin{array}{l}\text { Percaya diri, kreatif, dan pekerja keras (confidence, } \\
\text { assertiveness, creativity, resourcarefulness, courage, } \\
\text { determination and enthusiasm) }\end{array}$ \\
\hline 7 & $\begin{array}{l}\text { Kepemimpinan dan keadilan (justice, fairness, mercy, } \\
\text { ran }\end{array}$ \\
\hline
\end{tabular}

${ }^{20}$ Dharma Kesuma, DKK, Pendidikan Karakter Kajian Teori dan Praktik di Sekolah, (Bandung: PT. Remaja Rosdakarya, 2011), hal. 14.

Jurnal Ilmiah Al QALAM, Vol. 9, No. 17, Januari-Juni 2016 


\begin{tabular}{|c|l|}
\hline & leadership) \\
\hline 8 & $\begin{array}{l}\text { Baik dan rendah hati (kindness, friendliness, humility, } \\
\text { modesty) }\end{array}$ \\
\hline 9 & $\begin{array}{l}\text { Toleransi dan kedamaian dan kesatuan (tolerance, flexibility, } \\
\text { peacefulness, unity) }\end{array}$ \\
\hline
\end{tabular}

Dalam sistem Pendidikan karakter yang telah disusun dalam panduannya oleh Kementerian Pendidikan Nasional terdapat nilai-nilai yang akan membentuk karakter. Diantara lain ada 18 nilai: (1) Religius, (2) Jujur, (3) Toleransi, (4) Disiplin, (5) Kerja Keras, (6) Kreatif, (7) Mandiri, (8) Demokrasi, (9) Rasa ingin tahu, (10) Semangat kebangsaan, (11) Cinta tanah air, (12) Menghargai prestasi,

Bersahabat/komunikatif, (14) Cinta damai, (15) Gemar membaca, (16) Peduli Lingkungan, (17) Peduli sosial, (18) Tanggung jawab. ${ }^{21}$ Dan disampaikan juga meskipun telah dirumuskan 18 nilai pembentuk karakter bangsa, namun satuan pendidikan dapat menentukan prioritas pengembangannya untuk melanjutkan nilai-nilai prakondisi yang telah dikembangkan. Jadi sekolah masing-masing masih diberi kebebasan memilih nilai-nilai yang akan dikembangkan sesuai kondisi. ${ }^{22}$

Serta menurut Doni Koesoema $\mathrm{A}^{23}$ ada 12 pilar keutamaan pendidikan karekter: (1) Penghargaan terhadap tubuh, (2) Transendental, (3) Keunggulan akademik, (4) Penguasaan diri, (5) Keberanian, (6) Cinta kebenaran, (7) Trampil, (8) Demokratis, (9) Menghargai perbedaan, (10) Tanggung jawab, (11) Keadilan, (12) Integritas Moral.

${ }^{21}$ Kementerian Pendidikan Nasional, Panduan Pelaksanaan Pendidikan Karakter, (BALITBANG Pusat Kurikulum dan Perbukuan: Jakarta, 2011), hal. 8.

22 Dianjurkan dalam pemilihan nilai-nilai tersebut beranjak dari kepentingan dan kondisi satuan pendidikan masing-masing, yang dilakukan melalui analisis konteks, sehingga dalam implementasinya dimungkinkan terdapat perbedaan jenis nilai karakter yang dikembangkan antara satu sekolah dan atau daerah yang satu dengan lainnya. Implementasi nilai-nilai karakter yang akan dikembangkan dapat dimulai dari nilai-nilai yang esensial, sederhana, dan mudah dilaksanakan, seperti: bersih, rapi, nyaman, disiplin, sopan dan santun. Lihat Kementerian Pendidikan Nasional, Panduan Pelaksanaan Pendidikan Karakter......hal. 8.

23 Direktur Utama Pendidikan Karakter dan juga mengelola www.pendidikankarakter.orgdan disebut sebagai pembawa obor pendidikan karakter. meraih sarjana teologi di Universitas Gregoriana Roma Italia

Jurnal Ilmiah Al QALAM, Vol. 9, No. 17, Januari-Juni 2016 
Dari perumusan tersebut dapat kita lihat bahwa ada nilai-nilai karakter yang menjadi prioritas utama. Diantaranya adalah jujur, toleransi, demokrasi, suka menolong, cinta kedamaian. Karena kondisi Negara Indonesia saat ini dengan rusaknya moral dan semakin parah. Maka nilai-nilai itu yang dianggap sangat dibutuhkan. Dan kesemuanya itu adalah nilai-nilai kemanusiaan (Humanis) yang lebih mengutamakan perlakuan baik terhadap sesama manusia. Karena tujuan dari pendidikan karakter adalah menjadi manusia yang baik.

Perlu kita cermati bersama, bahwa nilai-nilai tersebut terlihat sangat baik dan sesuai dengan kemanusiaan. Tapi masih belum sepenuhnya bisa diterima oleh Islam dan masih harus dipertanyakan lebih mendalam. Seperti "Jujur", dalam Islam tak selamanya kita harus jujur kepada siapa saja. Ada porsi dan posisi serta kondisi yang harus dipertimbangkan. Sebagai contoh, ketika perang dan tertangkap menjadi tawanan. Maka ia sebagai seorang muslim tidak boleh jujur mengatakan dimana letak kelemahan kaum muslim walaupun harus mempertaruhkan nyawanya demi agamnya. Dan pada saat itu ia termasuk muslim yang berakhlak mulia. Selanjutnya "toleransi" yang bagaimanakah yang akan ditanamkan kepada seluruh anak didik dan generasi muda ini. Karena dalam Islam toleransi tidak bebas sebebas-bebasnya. Punya batasan apalagi jika sudah bersinggungan dengan akidah. ${ }^{24}$ Akan ada ketentuanketentuan yang harus diperhatikan lagi.

Doni Koesoema A menulis bahwa pendidikan karakter bertujuan membentuk setiap pribadi menjadi insan yang berkeutamaan. Dalam pendidikan karakter, yang terutama dinilai adalah perilaku, bukan pemahamannya. Doni membedakan pendidikan karakter dengan pendidikan moral atau pendidikan agama. Pendidikan agama dan kesadaran akan nilai-nilai religius menjadi motivator utama keberhasilan pendidikan karakter. Dan ia berpendapat agama tidak dapat dipakai sebagai pedoman pengatur dalam kehidupan bersama dalam sebuah masyarakat yang plural. "di zaman modern yang sangat multikultural ini, nilai-nilai agama tetap penting dipertahankan, namun tidak dapat dipakai

\footnotetext{
${ }^{24}$ Isma'il Raji Al-Faruqi, Tauhid, (Bandung: Penerbit Pustaka, 1988), hal. 49.
}

Jurnal Ilmiah Al QALAM, Vol. 9, No. 17, Januari-Juni 2016 
sebagai dasar kokoh bagi kehidupan bersama dalam masyarakat. Jika nilai agama ini tetap dipaksakan dalam konteks masyarakat yang plural, yang terjadi adalah penindasan oleh kultur yang kuat pada mereka yang lemah," tulisnya ${ }^{25}$.

Dalam pandangan Islam, pandangan sekularistik semacam itu, tentu tidak dapat diterima. Sebab, bagi Muslim, nilai-nilai Islam diyakini sebagai pembentuk karakter dan sekaligus dapat menjadi dasar nilai bagi masyarakat majemuk. Masyarakat Madinah yang dipimpin Nabi Muhammad saw, berdasarkan kepada nilai-nilai Islam, baik bagi pribadi Muslim maupun bagi masyarakat plural. Memang ada pengalaman sejarah keagamaan yang berbeda antara Katolik dengan Islam. ${ }^{26}$

Dalam soal pendidikan karakter bagi anak didik, berbagai agama dapat bertemu. Islam, Kristen dan berbagai agama lain dapat bertemu dalam penghormatan terhadap nilai-nilai keutamaan. Nilai kejujuran, kerja keras, sikap ksatria, tanggung jawab semangat pengorbanan, dan komitmen pembelaan terhadap kaum lemah dan tertindas, dapat diakui sebagai nilai-nilai universal yang mulia. Boleh jadi, masing-masing pemeluk agama mendasarkan pendidikan karakter pada nilai agama masing-masing.

Pendidikan akhlak dalam Islam, bukan hanya menanamkan nilainilai moral saja bahkan nilai-nilai ketaatan kepada Tuhan juga sudah dididik sejak dini. Serta mengembalikan semua fikiran, kehendak dan prilaku sesuai dengan fitrahnya ${ }^{27}$. Hormat kepada orang tua, menjaga sopan santun kepada sesama dan terkhusus lagi kepada yang lebih tua. Suka menolong sesama tanpa pamrih, jujur, meminta maaf dan mudah memberi maaf serta suka kebersihan semua sudah dilatih sejak kecil. Karena itu memang sudah fitrah manusia sejak diciptakan. Selain itu juga diajarkan untuk takut kepada balasan dari Allah sebagai sang Kholiq jika melanggar aturan-aturan itu. Maka setiap anak berbuat bukan hanya

${ }^{25}$ Adian Husaini, Pendidikan Islam....., hal. 44.

${ }^{26}$ Adian Husaini, Pendidikan Islam...... hal. 44.

${ }^{27}$ Fakhruddin Al-Raji, Kitab al-Nafs wa al-Ruh, (Pakistan: Islamic Research Institute, $1388 \mathrm{M} / 1968 \mathrm{H})$, hal. 2.

Jurnal Ilmiah Al QALAM, Vol. 9, No. 17, Januari-Juni 2016 
mengatasnamakan kemanusia, tapi juga ada nilai ketaatan kepada sang Kholiq didalamnya.

Jika disusun ada beberapa sifat penting dalam pendidikan akhlak, dapat dilihat sebagaimana berikut:

\begin{tabular}{|c|l|}
\hline No & \multicolumn{1}{|c|}{ Sifat } \\
\hline 1 & Beriman kepada Allah dan Rasul-Nya \\
\hline 2 & Ikhlas dalam beramal \\
\hline 3 & Gemar mancari ilmu \\
\hline 4 & Sabar menghadapi ujian Allah \\
\hline 5 & Akhirat tujuan utamanya \\
\hline 6 & Sangat takut kepada Allah dan ancaman-Nya \\
\hline 7 & Bertobat dan mohon ampun atas dosa-dosanya \\
\hline 8 & Shalat malam menjadi kebiasaannya \\
\hline 9 & Zuhud dunia dan mengutamakan akhirat \\
\hline 10 & Tawakal kepada Allah \\
\hline 11 & Senantiasa gemar berinfak \\
\hline 12 & Senantiasa berdakwah dan amar ma'ruf nahi munkar \\
\hline 13 & Kuat memegang amanah, janji, dan rahasia \\
\hline 14 & Bersikap santun kepada sesama manusia \\
\hline 15 & Cinta kasih dan penuh pengertian terhadap keluarga \\
\hline
\end{tabular}

Dapat dilihat bahwa orang yang berakhlak mulia dalam Islam selain dia melakukan kebaikan tapi juga harus taat kepada aturan Allah sebagai sang Kholiq. Jadi memiliki nilai keimanan yang kuat dalam setiap melakukan sesuatu. Baik itu berprilaku kepada sesama manusia (makhluk) dan juga kepada Allah (Kholiq). Nilai keimanan menjadi sesuatu yang sangat penting sekali dalam Islam. Inilah yang menjadi karakter seorang muslim dan berakhlak kepada Allah sesuai dengan ajaran Islam.

Memang kelihatannya tidak jauh berbeda antara pendidikan karakter dan pendidikan Akhlak. Karena sama-sama menanamkan nilai

Jurnal Ilmiah Al QALAM, Vol. 9, No. 17, Januari-Juni 2016 
kebaikan kepada setiap insan. Bahkan menurut Ratna Megawangi pendidikan karakter adalah untuk mengukir akhlak melalui proses knowing the good, loving the good, and acting the good. Yakni, suatu proses pendidikan yang melibatkan aspek kognitif, emosi, dan fisik, sehingga ahklak mulia dapat terukir manjadi habit of the mind, heart and hands. ${ }^{28}$ Namun yang menjadi nilai pembeda paling utama adalah keimanan yang kuat. Dalam Islam keimanan harus menjadi nomor satu. Tidak boleh dikesampingkan dengan alasan apapun. Jadi tidak sama dengan karakter yang ingin mencapai manusia baik saja namun menjauhkan diri dari Allah sang Kholiq.

Maka jika kita lihat kembali kepada nilai-nilai yang akan ditanamkan kepada generasi muda Indonesia di atas, maka ada beberapa poin yang bersinggungan dengan akhlak dalam Islam. Ini perlu kita waspadai selaku umat Islam yang ingin mempertahankan keislaman kita secara utuh dan sesuai syariat yang ada. Jangan mudah terikut dengan istilah-istilah yang menggiurkan. Seolah-olah dapat mengalahkan apa yang telah ada dalam Islam itu sendiri yaitu akhlak yang mulia. Karena memang tujuan nabi Muhammad Saw diutus untuk menyempurnakan kemuliaan akhlak manusia.

\section{Pendidikan Karakter Saja Tidak Cukup}

Jika bangsa Cina maju sebagai hasil pendidikan karakter, lalu apa bedanya orang komunis yang berkarakter dengan orang Muslim yang berkarakter? Orang komunis, atau ateis, dapat saja menjadi pribadi yang jujur, pekerja keras, berani, bertanggung jawab, mencintai kebersihan, dan sebagainya, kabarnya, di Jepang, jika ketinggalan barang di taksi hampir pasti akan kembali. Di Cina, masyarakat ditanamkan disiplin yang sangat tinggi dalam soal sampah. Di jalan-jalan sulit ditemukan sampah. Bahkan, sampah selembar daun pun dapat mereka manfaatkan untuk bahan bakar. Artinya, karakter yang bagus dapat dibentuk pada setiap manusia, tanpa memandang agamanya. Jika orang non-Muslim dapat berkarakter, orang muslim juga dapat seperti itu.

${ }^{28}$ Adian Husaini, Pendidikan Islam..... hal. 42.

Jurnal Ilmiah Al QALAM, Vol. 9, No. 17, Januari-Juni 2016 
Lalu, di mana perbedaan antara Muslim dan non-Muslim yang berkarakter? Bagi muslim, dia dapat juga dan bahkan harus berkarakter mulia. Tetapi, bagi muslim, berkarakter saja tidaklah cukup. Beda antara muslim dengan non-muslim -meskipun sama-sama berkarater- adalah pada konsep adab. Yang diperlukan oleh kaum muslim Indonesia bukan hanya menjadi seorang yang berkarakter, tetapi harus menjadi seorang yang berkarakter dan beradab. ${ }^{29}$

Istilah $a d a b$ juga merupakan salah satu istilah yang terdapat dalam pendidikan akhlak sebagai landasan dasar dalam Islam. Para ulama telah banyak membahas makna adab dalam pandangan Islam. Istilah adab dapat ditemukan dalam sejumlah hadits Nabi saw. Misalnya, Anas ra meriwayatkan, bahwa Rasulullah saw pernah bersabda:

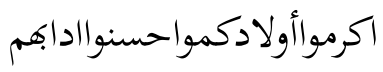

(Muliakan anak-anakmu dan perbaikilah adab mereka.) (HR. Ibn Majah)

Pendiri Nahdlatul Ulama, KH Hasyim Asy'ari, misalnya dalam kitabnya, Adabul Alim wal-Muta'allim, mengutip pendapat Imam alSyafi'i yang menjelaskan begitu pentingnya kedudukan adab dalam Islam. Bahkan, sang Imam menyatakan, beliau mengejar adab laksana seorang ibu yang mengejar anak satu-satunya yang hilang.

Secara umum, menurut Kyai Hasyim Asy'ari, tauhid mewajibkan wujudnya iman. Barangsiapa tidak beriman, maka dia tidak bertauhid; dan iman mewajibkan syariat, maka barangsiapa yang tidak ada syariat padanya, maka dia tidak memiliki iman dan tidak bertauhid; dan syariat mewajibkan adanya adab; maka barangsiapa yang tidak beradab maka (pada hakikatnya) tiada syariat, tiada iman, dan tiada tauhid padanya. ${ }^{30}$

${ }^{29}$ Adian Husaini, Pendidikan Islam..... hal. 49.

30 Hasyim Asy'ari, Adabul Alim wal-Muta'allim, (Jombang: Maktabah Turats Islamiy, $1415 \mathrm{H})$, hal. 11.

Jurnal Ilmiah Al QALAM, Vol. 9, No. 17, Januari-Juni 2016 
Jadi, betapa pentingnya kedudukan adab dalam ajaran Islam. Lalu, apa sebenarnya konsep adab? Uraian yang lebih rinci tentang konsep adab dalam islam disampaikan oleh Prof. Syed Muhammad Naquib al-Attas, pakar filsafat dan sejarah Melayu. Menurut Prof. Naquib al-Attas :

Adab adalah pengenalan serta pengakuan akan hak keadaan sesuatu dan kedudukan seseorang, dalam rencana susunan berperingkat martabat dan derajat, yang merupakan suatu hakikat yang berlaku dalam tabiat semesta. Pengenalan adalah ilmu; pengakuan adalah amal. Maka, pengenalan tanpa pengakuan seperti ilmu tanpa amal; dan pengakuan tanpa pengenalan seperti amal tanpa ilmu. Keduanya sia-sia karena yang satu mensifatkan keingkaran dan keangkuhan, dan yang satu lagi mensifatkan ketiadasedaran dan kejahilan. ${ }^{31}$

Begitu pentingnya masalah adab ini, maka dapat dikatakan, jatuhbangunnya umat Islam, tergantung sejauh mana mereka dapat memahami dan menerapkan konsep adab ini dalam kehidupan mereka. Manusia yang beradab terhadap orang lain akan paham bagaimana mengenai dan mengakui seseorang sesuai harkat dan martabatnya. Martabat ulama yang shalih beda dengan martabat orang fasik yang durhaka kepada Allah. Jika Allah swt menyebut dalam al-Qur'an, bahwa manusia yang paling mulia di sisi Allah adalah yang paling taqwa ${ }^{32}$, maka seorang yang beradab tidak akan lebih hormat kepada penguasa yang zalim ketimbang guru mengaji yang shalih di kampung. Dalam masyarakat yang beradab, seorang penghibur tidak akan lebih dihormati ketimbang pelajar yang memenangkan olimpiade fisika. Seorang pelacur atau pezina ditempatkan pada tempatnya, yang seharusnya tidak lebih tinggi martabatnya dibandingkan muslimah-muslimah yang shalihah. Begitulah akhlak kepada sesama manusia dalam Islam.

Akhlak juga terkait dengan ketauhidan, sebab akhlak kepada Allah mengharuskan seorang manusia tidak merserikatkan Allah dengan yang lain. Tindakan menyamakan Kholiq dengan makhluk merupakan tindakan

\footnotetext{
${ }^{31}$ SM Naquib al-Attas, Risalah untuk kaum Muslimin, (ISTAC, 2001), hal. 85.

${ }^{32}$ QS al-Hujurat: 13
}

Jurnal Ilmiah Al QALAM, Vol. 9, No. 17, Januari-Juni 2016 
yang tidak berakhlak. Karena itulah, maka dalam al-Qur'an disebutkan, Allah murka karena Nabi Isa As diangkat derajatnya dengan Kholiq, padahal ia adalah makhluk. Tauhid adalah konsep dasar bagi pembangunan manusia beradab. Menurut pandangan Islam, masyarakat berakhlak haruslah meletakkan Kholiq pada tempat-Nya sebagai Kholiq, jangan disamakan dengan makhluk. ${ }^{33}$

Itulah akhlak kepada Allah swt. Nabi Muhammad Saw adalah juga manusia. Tetapi, beliau berbeda dengan manusia lainnya karena beliau adalah utusan Allah. Sesama manusia saja tidak diperlakukan sama, apa lagi kepada utusan Allah yang mulia. Seorang presiden dihormati, diberi pengawalan khusus, diberikan gaji yang lebih tinggi dibandingkan gaji guru mengaji, dan sering disanjung-sanjung, meskipun kadangkala keliru. Makanya orang berebut untuk menjadi presiden karena menganggap presiden merupakan kedudukan terhormat dan memiliki kekuasaan besar sehinga dapat melakukan perubahan. ${ }^{34}$ Dan mereka juga sudah merasa bahwa darinya memiliki karakter yang kuat dan cukup untuk memberikan perubahan di dalam negara.

Karakter yang juga dimaknai sebagai sifat yang dimainkan seorang aktor dalam sebuah sandiwara, drama, atau lakon. Berkarakter baik bisa diartikan sebagai ber-"peran" baik dengan sifat-sifat yang diberikan kepadanya. Ia bukan sifat yang melekat erat dalam identitas diri. Bukan dorongan jiwa melainkan dorongan masyarakat. Mungkin tampak sangat manusiawi, tapi tidak yang mesti berdimensi Ilahi. ${ }^{35}$

Sering kita temui pemimpin yang sangat berkuasa dan punya pengaruh yang luar biasa di masyarakat. Mampu menyelesaikan berbagai macam masalah dengan cepat dan tepat dihadapan manusia. Tindakannya selalu tegas serta punya prinsip yang susah untuk digoyahkan. Dia dikatakan memiliki karakter yang kuat. Walaupun ternyata dibalik itu dia memiliki wanita idaman lain (WIL). Dan tidak pernah melaksanakan sholat ataupun mungkin puasa sesuai perintah agama. Tapi dia tidak dapat disebut sebagai pemimpin yang berakhlak.

\footnotetext{
${ }^{33}$ Adian Husaini, Pendidikan Islam..... hal. 51.

${ }^{34}$ Adian Husaini, Pendidikan Islam..... hal. 52.

${ }^{35}$ Hamid Fahmy Zarkasyi, Akhlak, dalam Republika-Islamia, 15 September 2011.
}

Jurnal Ilmiah Al QALAM, Vol. 9, No. 17, Januari-Juni 2016 
Menurut Hamid Fahmy Zarkasyi memaknai akhlak jangan sesempit memaknai moral. Berakhlak yang sempit hanya berpedoman halal-haram atau wajib-sunah. Hubungannya dengan Tuhan tidak disempurnakan dengan hubungan antarmanusia (mu'amalah ma'annas). Ibadahnya sempurna, pakaiannya sederhana, lidahnya fasih melantunkan ayat-ayat-Nya. Tapi, tindakan dan ucapannya menyakiti sesamanya atau orang-orang di bawahnya. Inilah makna berakhlak yang salah. ${ }^{36}$ Maka jangan heran jika ada tokoh agama yang terjerumus skandal tahta, harta, dan wanita.

Orang baik atau good $\operatorname{man}^{37}$, harusnya adalah manusia yang berkarakter dan berakhlak. Tidak cukup seorang memiliki berbagai nilai keutamaan dalam dirinya, tetapi dia tidak ikhlas dalam mencari ilmu, enggan menegakkan amar ma'ruf nahi munkar, dan suka mengumbar aurat serta maksiat. Pendidikan menurut Islam, haruslah bertujuan membangun karakter dan akhlak sehingga tercapai akhlak yang mulia.

Karena karakter, pada umumnya adalah sesuatu yang baik. Karakter jujur, toleran, kerja keras, dan sebagainya, memang sesuatu yang didambakan manusia. Namun tanpa disertai akhlak, karakter itu akan dapat melampaui batas-batas ajaran agama. Sebagai contoh, karakter toleran. Toleransi saja tidak cukup. Toleran terhadap apa? Seorang muslim tidak boleh bersikap toleran terhadap kemusyrikan atau kemunkaran. Sebab, setiap muslim berkewajiban menjalankan amar ma'ruf nahi munkar. ${ }^{38}$,

\section{Kesimpulan}

Dengan demikian maka dapat kita lihat bahwa pendidikan karakter belum sepenuhnya dapat dijadikan rujukan untuk mengatasi masalah pendidikan yang ada di negara ini. Karena hanya menitikberatkan kepada nilai-nilai dan norma-norma kemanusiaan saja. Hanya mencetak manusia yang mengetahui kebaikan (knowing the good), mencintai kebaikan (loving the good), dan melakukan kebaikan (doing the good) kepada sesama makhluk, tapi miniadakan ketauhidan ilahiyah. Lebih jauh lagi

\footnotetext{
${ }^{36}$ Hamid Fahmy Zarkasyi, Akhlak, dalam Republika-Islamia, 15 September 2011.

${ }^{37}$ Yang menjadi tujuan pendidikan karakter

${ }^{38}$ Adian Husaini, Pendidikan Islam..... hal. 54.
} 
secara tidak langsung akan menjauhkan kita dari sang Kholiq (Allah). Dalam pendidikan karakter juga menganggap bahwa agama bukan suatu yang mendasar untuk menciptakan manusia yang baik apalagi di negara yang plural. Maka hanya dengan pendidikan karakter saja, justru akan membahayakan bagi akidah umat Islam.

Pendidikan akhlak yang terdapat dalam pendidikan Islam akan menyempurnakan semua itu. Karena berakhlak adalah berpikir, berkehendak, dan berperilaku sesuai dengan fitrahnya (nurani) untuk terus mengabdi kepada Allah. Jadi bukan hanya menjadi manusia baik yang berkarakter tapi juga berakhlak mulia. 


\section{DAFTAR PUSTAKA}

Al-Qur'anul Karim

Al-Attas, Syed Muhammad Naquib. Risalah untuk kaum Muslimin. Malaysia: ISTAC, 2001

Al-Faruqi, Isma'il Raji. Tauhid. Bandung: Penerbit Pustaka, 1988

Al-Ghazali. Ihya Ulumuddin. Qairo, Mesir: Daar al-Taqwa, 2000

Al-Raji, Fakhruddin. Kitab al-Nafs wa al-Ruh. Pakistan: Islamic Research Institute, $1388 \mathrm{M} / 1968 \mathrm{H}$

Asy’ari, Hasyim.Adabul Alim wal-Muta'allim. Jombang: Maktabah Turats Islamiy, $1415 \mathrm{H}$

Badaruddin, Kemas. Filsafat Pendidikan Islam: Analisis Pemikiran Syed Muhammad Naquib al-Attas. Yogyakarta: Pustaka Pelajar, 2009

Husaini, Adian. Pendidikan Islam Membentuk Manusia Berkarakter dan Beradab. Depok: Kemunitas NuuN, 2011

Kesuma, Dharma (dkk). Pendidikan Karakter Kajian Teori dan Praktik di Sekolah. Bandung: PT. Remaja Rosdakarya, 2011

Kementerian Pendidikan Nasional. Panduan Pelaksanaan Pendidikan Karakter. Jakarta: BALITBANG Pusat Kurikulum dan Perbukuan, 2011

Lickona, Thomas. Educating For Character: How Our School Can Teach Respect and Responsibility. New York: Bantam Books, 1992

Jurnal Ilmiah Al QALAM, Vol. 9, No. 17, Januari-Juni 2016 
Luthfiah, Zeni (dkk). Pendidikan Agama Islam: Pendidikan Karakter Berbasis Agama Islam. Surakarta: Yuma Pustaka, 2011

Majid, Abdul dan Andayani, Dian. Pendidikan Karakter Perspektif Islam. Bandung: PT. Remaja Rosdakarya, 2011

Miskawaih, Ibnu. Tahdzib al-Akhlak. Beirut: Dar el Kutb al-Taymiyyah, $1405 \mathrm{H} / 1985 \mathrm{M}$

Sudewo, Erie. Best Practice Charater Building Menuju Indonesia Lebih Baik. Jakarta: PT Gramedia, 2011

Setiawan, Agus. Prinsip Pendidikan Karakter dalam Islam (Studi Komparasi Pemikiran al-Ghazali dan Burhanuddin al-Zarnuji), Dinamika Ilmu, 14 (1), 2014.

Tufiq, Ahmad. Pendidikan Agama Islam: Pendidikan Karakter Berbasis Agama Islam. Surakarta: Yuma Pustaka, 2011

Wibowo, Agus. Pendidikan Karakter Strategi Membangun Karakter Bangsa Berperadaban. Yogyakarta: Pustaka Pelajar, 2012

www.pendidikankarakter.org

Zarkasyi, Hamid Fahmy. Akhlak. Republika-Islami

Jurnal Ilmiah Al QALAM, Vol. 9, No. 17, Januari-Juni 2016 